\title{
名古屋市の水循環施策「水の環復活2050なごや戦略」について
}

\author{
木綿愛子*

\section{Nagoya strategy that revives hydrological cycle in 2050}

\author{
Aiko MOMEN*
}

1.はじめに

名古屋市では，2003年度より，健全な水循環の 回復という視点で施策を検討・実施している。今 回はその概要や進渉状況, 課題等を紹介する他, 今般制定された水循環基本法及び水循環基本計画 と本市の施策との関係についての所感と, 地下水 研究者の皆様に期待することを述べる。

\section{2.「水の環復活2050なごや戦略」の概要及び進 渉状況等}

\section{1 健全な水循環の回復に関する経緯}

健全な水循環の回復について，本市での公式な 動きは, 表 1 に示すように「市民の健康と安全を 確保する環境の保全に関する条例（2003年度）」 の条文に記載されたことが始まりである。この条 例を受ける形で，健全な水循環の回復に関する現
状確認と施策の構想として「水の環復活プラン (2007年度)」を策定し, その後, 構想を具体化す るものとして「水の環復活2050なごや戦略（2009 年度)」(名古屋市, 2009a) を策定した。この戦 略を, 以下では水の環戦略という。

水の環戦略は, 図 1 に示すように2050年とい う, やや遠い将来に実現したい都市像を大胆に描 き，そこから今やるべきことを考えるという手法 で作られている。各局としては, 限られた予算で 既存の仕事をこなしながらの取り組みとならざる を得ず，現状の取り組みを積み上げる手法では大 きな目標が掲げにくいが，どう実現するかは少し 曖昧なまま残しつつ, 将来の「めざす姿」を揭げ るという前提だからこそ, 各局が合意して策定で きたと感じている。

本市では, 水の環戦略のほか, 「生物多様性 2050なごや戦略」(名古屋市, 2010), 「低炭素都 市2050なごや戦略」(名古屋市，2011）のあわせ

表 1 健全な水循環の回復に関する名古屋市のこれまでの動き

\begin{tabular}{|l|l|}
\hline 2003 年 & 市民の健康と安全を確保する環境の保全に関する条例 \\
\hline 2007 年度 & 水の環復活プラン \\
\hline 2009 年度 & 水の環復活 2050 なごや戦略, 同第 1 期実行計画 (〜2012 年) \\
\hline$（ 2014$ 年 $)$ & （水循環基本法） \\
\hline 2014 年度 & 第 2 期実行計画 ( 2025 年 ただし 2020 年に中間評価) \\
\hline$(2015$ 年 $)$ & （水循環基本計画） \\
\hline
\end{tabular}

括弧内は国の動き

* 名古屋市環境局地域環境対策課（干460-8508 愛知県名古屋市中区三の丸3-1-1）

Regional Environment Policies Division, Environmental Affairs Bureau, City of Nagoya 
て三つの戦略を，環境局が中心となって，類似の 手法で策定しており，また，「第 3 次名古屋市環 境基本計画」(名古屋市, 2009b) では, 2050年 の環境都市ビジョンとして「土・水・緑・風が復 活し，あらゆる生命が輝くまち」を掲げ，三つの 戦略が互いに深く関係していることが示されてい る。

さて，水の環戦略では，2050年までを三つの 期間に分けて実行計画を策定し, 現在は第 2 期 （2012年～2025年）実行計画に基づき, 施策の推 進と進行管理を行っている。実行計画は, 将来の 都市像の実現のため「今やるべきこと」と「今で きること」を近づける努力をしながら記載してい る。

現在の目標は, いずれも2020年に「水収支（蒸 発散 $25 \%$ : 浸透貯留 $18 \%$ : 直接流出 $57 \%)$, 「名 古屋の河川の水がきれいだと思う市民の割合 40\%」，「身近に自然や農とふれあうことができる 場所がある市民の割合50\%」などを達成すること としている。その他, 浅層地下水の状況や湧き水
の量, 水循環について理解している市民の割合, 家庭で雨水浸透ますや雨水タンクを設置している 市民の割合等も指標としていくこととしている。

\section{2 雨水流出抑制の取り組み}

本市では, 健全な水循環の回復という視点に先 行する昭和の時代から, 防災の観点で雨水流出抑 制の取り組みが行われてきた。現在, 市の施設に ついては「名古屋市雨水流出抑制実施要綱」によ り，原則として雨水の浸透・貯留の実施が義務付 けられており，また民間にも対してもその実施を 促すこととされている。

雨水流出抑制については, 上下水道局が事務局 となって取り組み状況のとりまとめ等を行い, そ の数值は水の環戦略での水収支の算出にも活用さ れ，また水の環戦略を所管する環境局と合同で民 間に対する浸透貯留の PR を行うなど，連携して 取り組んでいる。

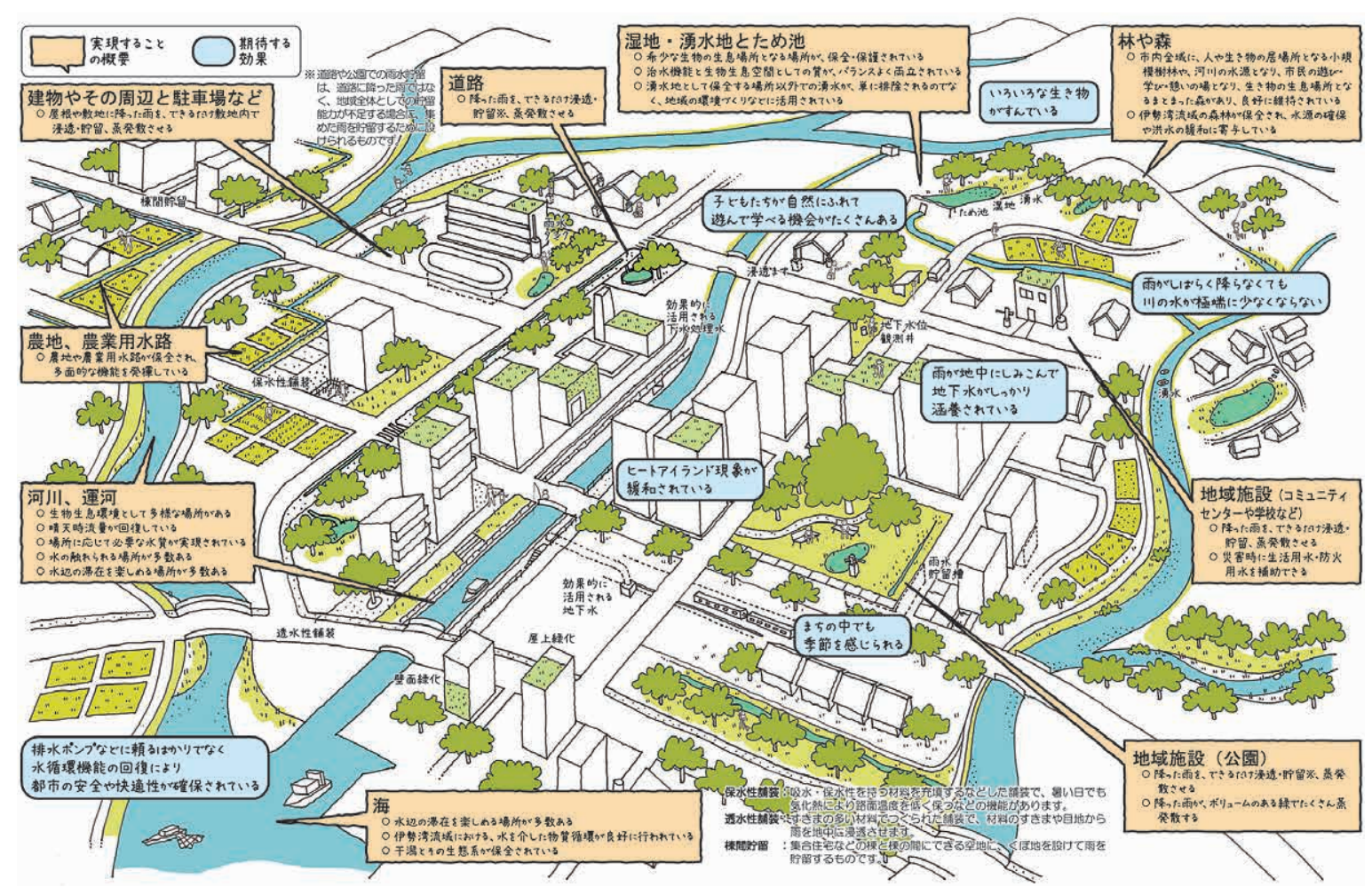

図 1 水循環の観点から 2050 年を目途に実現したい名古屋の姿［第 2 期実行計画より] 


\section{3. 現在の進渉状況}

\section{1 水収支}

「水の環復活2050なごや戦略」では，いくつか の指標と目標を設定しているが, このうち最も基 本的かつ重要なものが「水収支」である。水収支 については，図 2 に示すように都市化の進む市の これまでの水収支と2050年の数值目標が掲げら れ, 図 3 では2050年の数值目標を揭げるととも に，これを実現するための取り組みの組み合わせ 例を示している。

計算上，水収支に影響するものは，主に浸透・ 貯留施設の設置状況と緑被率である。

\section{（1）浸透・貯留施設}

市の施設（道路・公園等を含む）については, 前述のとおり浸透貯留が義務化されており, 施設 の改修等にあわせて，着実に実施している。民間 に対しては，図 4 に示す浸透適地マップ (平成21 年度作成）を使う等して協力を依頼し, 民有地で の実施状況の把握と, さらなる協力をどう得てい くかが課題となっている。

\section{(2) 緑被率}

本市の緑被率は, 1990年29.8％, 2015年に
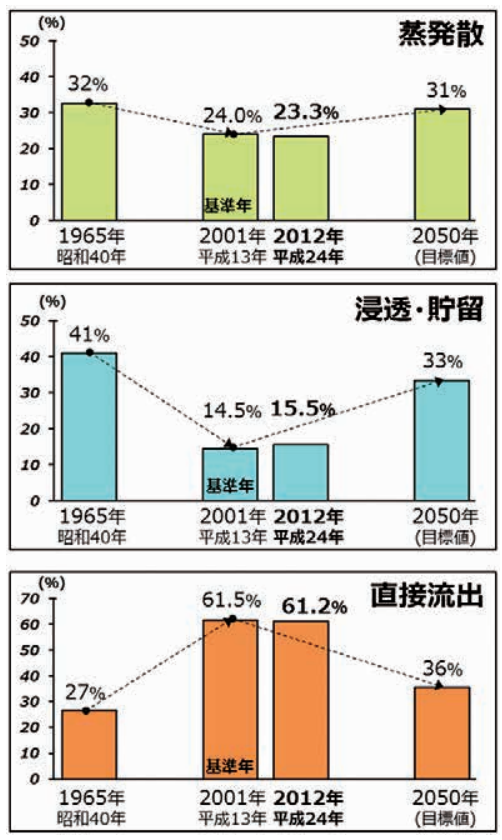

図 2 これまでの水収支と 2050 年目標 との比較 [第 2 期実行計画より]
$22.0 \%$ と, 市街化に伴って低下傾向にある。本市 では, 緑の維持・保全のための施策は様々実施さ れているが，例えば，緑政土木局が所管する緑化 地域制度により，一定規模以上の敷地において建 築を行う場合に，敷地の10〜20\%の緑化が義務付 けられている。

\section{（3）その他}

環境局としては, この他, 打ち水大作戦や緑の カーテン事業の実施など, 健全な水循環の回復に 寄与し，また水循環機能を活かす生活スタイルの 啓発も行っている。これらは小規模で定量化が難 しいものであるが，市民一人ひとりが取り組みや すく，また水の環復活に協力している実感を得や すい, 大切な要素と考えている。

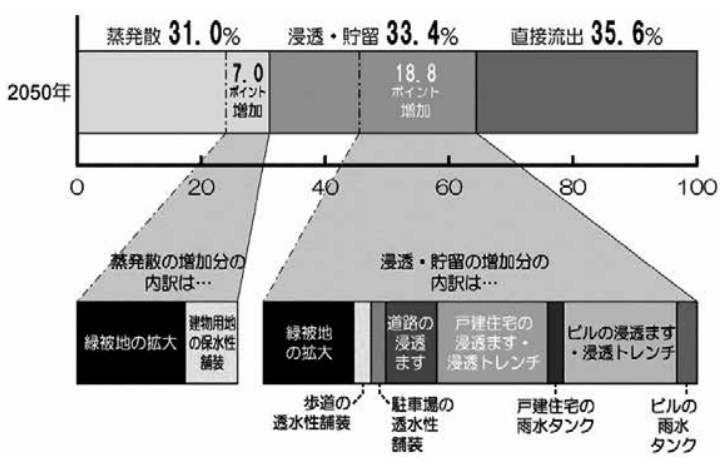

図 3 水収支の目標と取り組みの組み合わせ例 [水の環戦 略より]

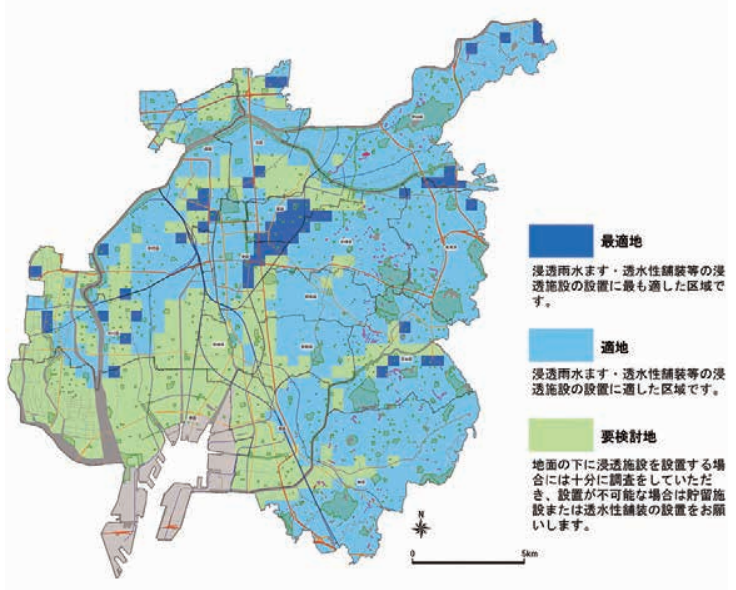

図 4 浸透適地マップ 


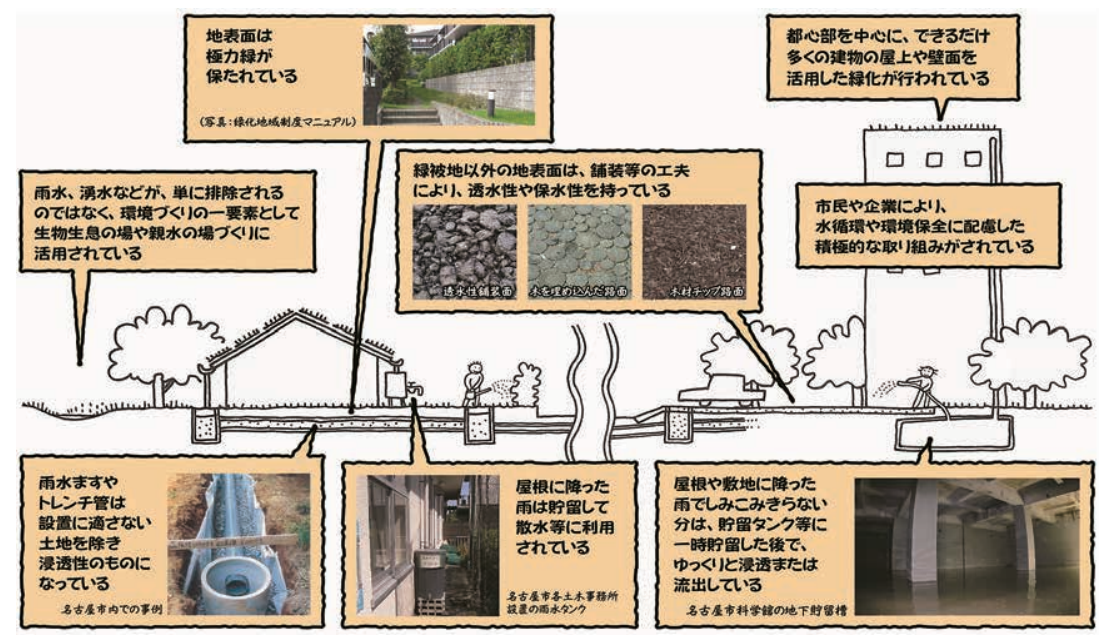

図 5 場所ごとに目指したい姿（建築物とその周囲や駐車場）[第 2 期実行計画より]

\section{2 みんなで取り組む人づくり・場づくり}

水の環戦略では, 水収支の他にも指標を設定し ている。そのひとつに,「水循環について理解し ている市民の割合」がある。平成24年に，市民を 対象にアンケートを実施したところ，「水循環と

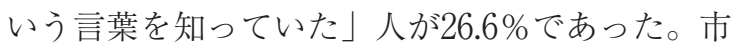
域の約 6 割が民有地ということもあり，水収支の 目標達成や, めざす姿の実現に向け, 市民, 事業 者等の理解の促進が必要と考えている。

\section{3 水循環機能を活かした，人にも生き物に もやさしいまちづくり}

大雨などの非常時だけでなく，また森や農地だ けでなく，多くの市民が日頃から，気持ちよい暮 らしができていると感じられることも大切であ る。水の環戦略では, 例えば, 図 5 に示すように 「建築物とその周囲や駐車場に関する取り組み」 として,「雨水・湧水などが，単に排除されるだ けではなく, 環境づくりの一要素として生物生息 の場や親水の場づくりに活用されている」と記し ており，水収支が改善するだけでなく，それに伴 う効果をうまく活用して豊かな日常生活の場づく りを行うことが示されている。

一方, 図 6 に示すように都市化による市の抱え る問題や水循環の様相の変化に対応することも急 務である。しかし, 各局には, 例えば道路や公園 を安全に管理するなど絶対に外せない仕事があ り，予算的に厳しい昨今の状況下で，こうした仕
事を行うのが精一杯という実情がある。健全な水 循環が回復し，その恩恵を生かすことができれ ば，例えば，ヒートアイランド現象が緩和され空 調負荷が減る，涼しい街中で季節を楽しむ大人が 増える，水質が良くなった水辺で子どもたちがい ろんな経験をして名古屋の誇りにつながっていく など素晴らしい役割が期待されるが，そうした効 果の定量化は簡単ではない。

また，特定の池の涵養域に透水性舗装や浸透ま す等を設置し, 地下水の湧出を増やして水質を改 善し, 豊かな水辺をつくりたいというような場 合, 実際には湧水の増加のみではそれほど大きな 改善は見込めないとか, 湧出には護岸を作り変え る必要があるとか, 定期的な池干しが必要とか, 生物のために池の周囲に湿地がなければいけない など, 手間や空間が必要になることも考えられ る。

さらに, 湧水地点と湧水を利用したい地点が, かなり近くないと上水道や井戸を使うことに対す るメリットが見出しにくいということもある。浸 透を促進し，湧き水を豊かにし、光いうと，地形 や気候といった風土を生かすことにつながる美し いイメージがあるが，密集した都市域で地下水が 湧出するのは, ビル地下や地下鉄, ドライエリア 等が多く, 湧水地点の近くには活用の場所が無 い,といったことも十分考えられる。美しいイ メージを打ち出すたけげなく, リアルな場所で, 環境づくりや持続可能な都市づくりにつなげるよ 


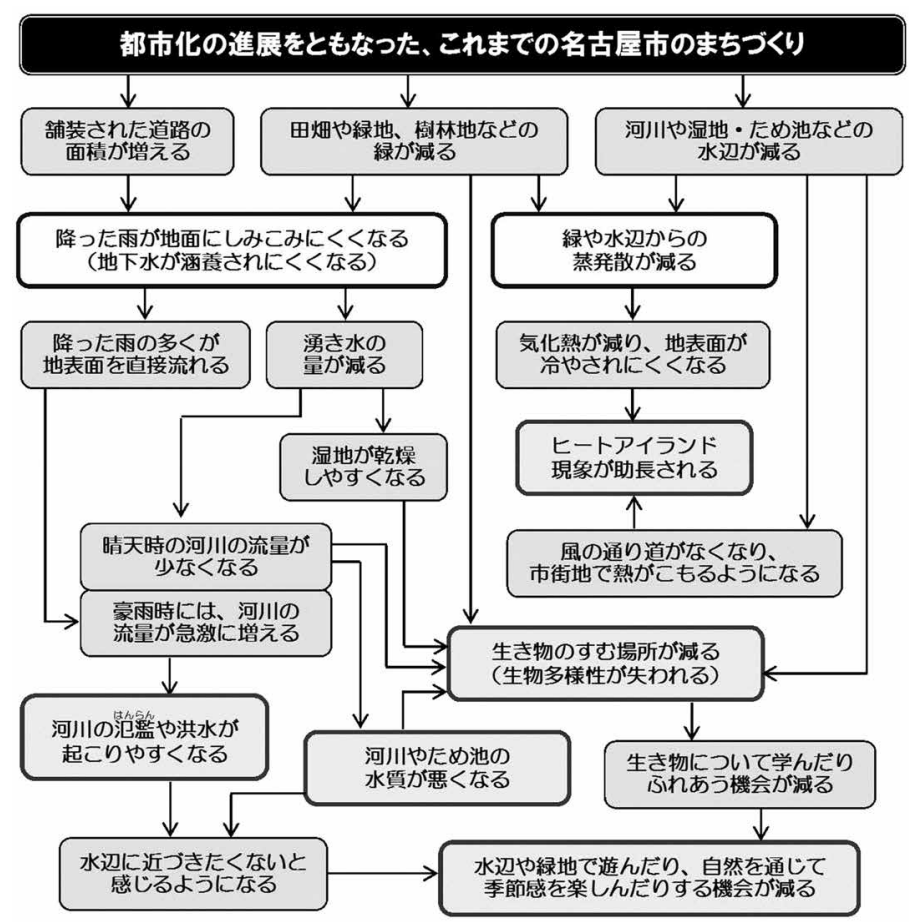

図 6 都市の抱える問題と水循環の関係

う, 少しずつ知見と実例を作っていく必要を感じ ている。

\section{4 モデル事業}

本市では, 水循環に対する市民の理解度が低い ことを受け，目に見える形で施策を展開し，水循 環の大切さや課題を広く知っていただこうと, モ デル事業に取り組んでいる。モデル事業の一つ は，1分間あたり約100Lの地下水が湧き出して いる市の鶴舞中央図書館のドライエリア（図 7 参 照）に，市民が立ち寄り，見たり触ったりでき るよう整備する内容である。訪れた人には, 大都 市の足元にも地下水が流れていることに気づき, 水循環とは何か, またその課題を知り, 水循環に 配慮する行動を実践していただきたいが，それた けでなく, 地下水から地形へ, 地形から街の歴史 へと興味を深めたり，さらに歴史等への興味から 入って環境にも視野を広げてもらったり，という 仕掛けになればと考えている。

モデル事業のもう一つは, 市の周縁部の住宅地 にあり，もともと里山として利用され，現在でも

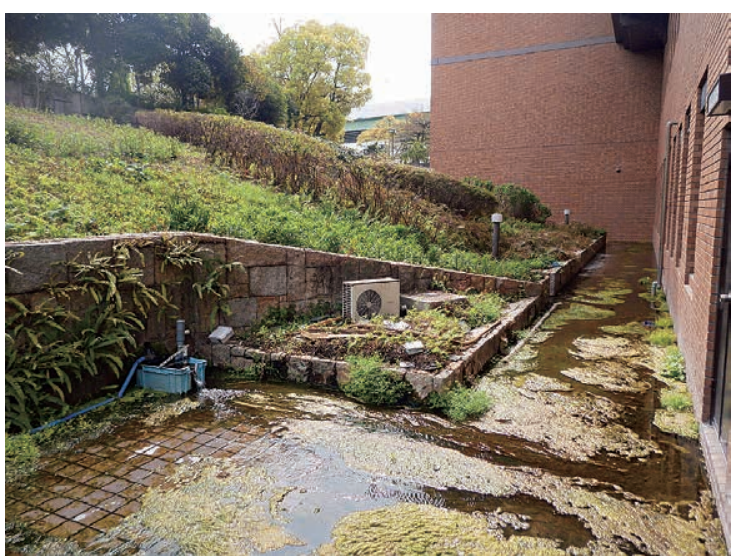

図 7 鶴舞中央図書館ドライエリアの湧き水

その面影を残す緑地において，水循環の視点から 図 8 の流向調査結果を活かしたツアー等を行う内 容である。参加者には，健全な水循環が損なわれ る以前の，私たちが水循環の恩恵をうまく生かし ていた頃のことを知ってもらい, やはり水循環と は何か, またその課題を学び, 自らの行動につな げていただくことが目的である。 
地下水学会誌 第 60 巻第 2 号 $123 \sim 130$ (2018)

一方，この緑地について，現地で活動している 方々と関わる中で，市内としては良い状態が残さ れた緑地であるものの，水循環に関わる課題が多 くあることがわかってきた。例えば，両生類の産 卵が盛んに行われていた湿地の縮小, 竹藪の拡大 などである。こうしたことについて，里山の水循
環を再生するにはどうするとよいか，といった観 点で調査をしようとしているところである。

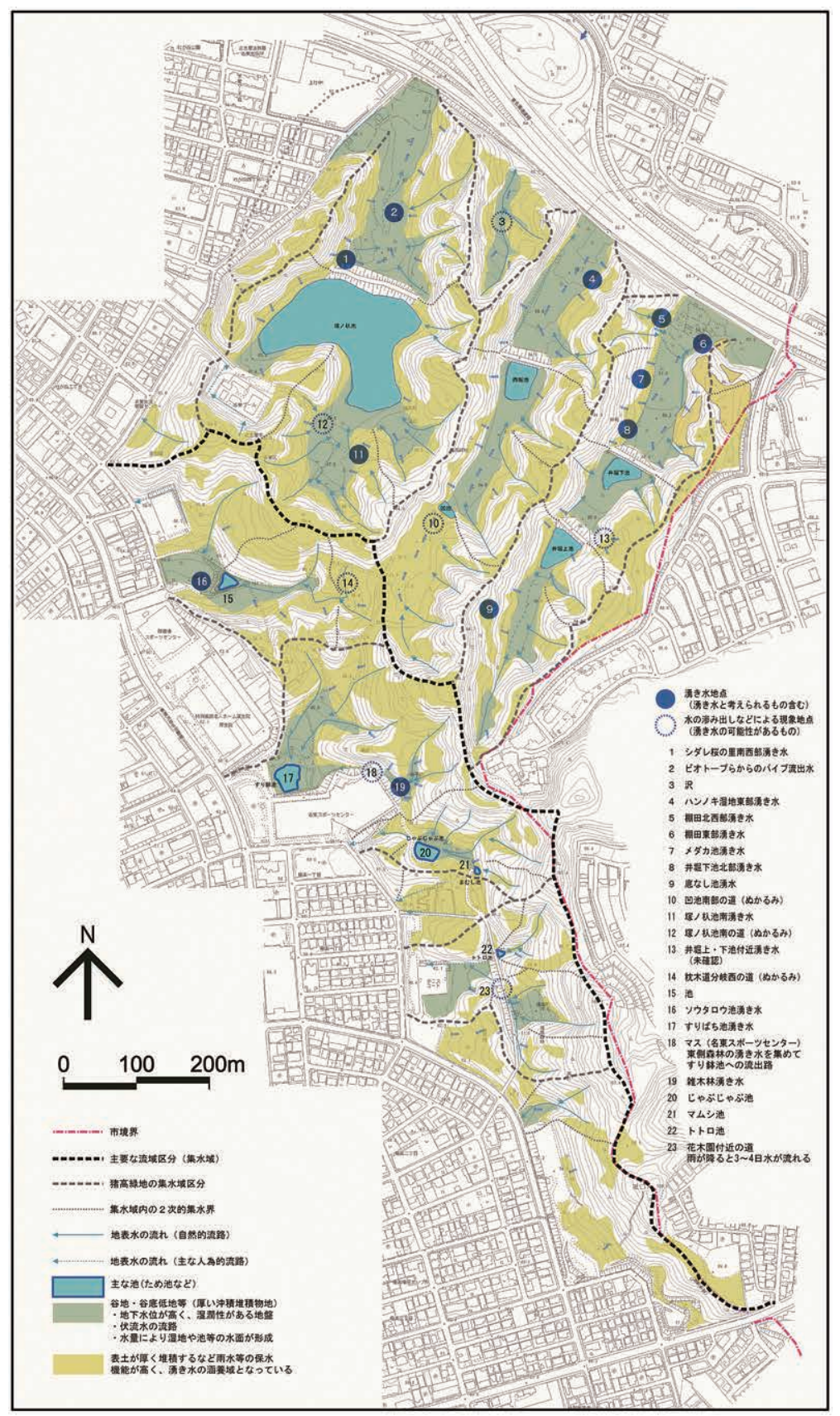

図 8 猪高緑地流向調査結果（2016.3.31） 


\section{4. 水循環基本計画の下での水循環施策について}

\section{1 本市の体制}

水循環基本計画の総論の 2 に,「水循環に関わ る施策については，これまで幅広い分野に及ぶ多 種多様な個別の施策が講じられてきているが，今 後は健全な水循環の維持又は回復という目標を共 有し，これら個別の施策を相互に連携・調整しな がらすすめていくことが重要である。また, 政府 全体で総合的に調整しながらすすめていくことが 必要となる施策も多い。こうしたことから，水循 環に関する施策を総合的かつ一体的に推進する こと等を目的に，平成 26 年 7 月に法が施行され た。」とある。

水の環戦略も，これまで個別的に行ってきたイ ンフラ整備をはじめとする施策や, 市民のくら し, 事業活動等を, 健全な水循環の回復に寄与 し, 水循環機能を活かすかたちにシフトしていく ことを目指している。しかし一方, 水の環戦略 は, 各分野の計画の上位にあるものではなく, や や遠い未来を大胆に描くという前提の下で各局の 協力を得ているもので, 法の下の計画とは馴染ま ない部分がある。

一方, 本市の総務局には, 水に倸る施策の調整 担当が置かれており, 水循環基本法への対応につ いては，こちらが情報収集や取りまとめを行って いるところである。平成27年11月から, 水施策に かかる連絡調整会議（関倸局の課長級会議）を開 催し, 水循環基本計画に照らして, 本市の取り組 みが十分かどうかの検討等を行っている。

上下水道局, 緑政土木局, 総務局, 環境局など 様々な局が登場し, 縦割りという印象を与えるか もしれないが, 健全な水循環の回復は, もともと 分野ごとに考えを持って仕事をしてきた市役所の 様々な仕事に関わる理念であり，すぐに一致団結 して合意形成ができるものではないし，多岐に渡 る関係施策を一手に取りまとめる受け皿が無いの も現状である。いろいろなきっかけを捉えて，水 循環に関わる施策が良い方向に動いていくよう， 協力していきたいと考えている。

\section{5. 地下水研究者の皆様に期待すること}

これまで述べてきたように，「水循環に関する 施策」というと実に多岐にわたり，またそれぞれ が複雑に関倸している。そのため, 実際のどこか のフィールドで, 仮説に基づき何かを実施し，観 測, 分析し, 実施内容を見直し, いずれ軌道に乗 せていくという流れが大切になると感じている。

仮説を立てるところから分析に至るまで, 行政 担当者としては，ほとんど手探りの状態である。 本市では,「なごや水の環復活推進懇談会」を設 け，大同大学の大東教授はじめ 7 人の専門家と 2 人の市民から意見をいただくことができるが，こ れがなければ，専門的なことがほとんどわからな いといっても過言ではない。研究者の皆様には, 行政職員から水循環の関係で声がかかったとき, できる限り，ご助言いただけたらと思っている。

な㧍，本市では，啓発を主な目的として，市内 の湧き水10地点で, 市民モニターグループに湧き 水の水量 ·水質・温度などを調べる「湧き水モ二 タリング」と, 河川・ため池の水質を調べる「水 質環境目標值市民モニタリング」も実施してい る。こうした方々との情報交換も，我々職員に とっては市民から見た水循環関係施策のあり方を 考える上で，良い刺激になっている。

一方, 研究者の方からの情報提供も歓迎であ る。「こんな調查を考えているが, 施策と結びつ くフィールドはあるだろうか。」といった投げか けも良いと思う。専門知識や調査経験のある研究 者の方と一緒に, いろいろな実例を作っていくよ うなことができれば，素晴らしいと考える。

また，行政職員が調查等を立案する場合に，そ の業務を得意とする事業者を探すが，どの企業が 専門知識や技術を持っているのか，なかなか情報 がつかめない。問い合わせ空口や，情報提供の ウェブサイトなどがもしあるのなら，活用したい と思っている。積極的な情報発信をしていただけ るとありがたく思う。

\section{6. まとめ}

以上, 本市の状況と, 担当者として日頃感じて いることを述べさせていただいた。これまで分野 
地下水学会誌 第 60 卷第 2 号 $\quad 123 \sim 130$ (2018)

ごとの考えで行ってきた施策に, 水循環という横 糸を通すのは, 通す側, 受け入れる側双方にとっ て, 相当の議論と時間, 知恵と決断が必要であ る。専門家の皆様のご協力をお願いする。

\section{参考文献}

名古屋市 (2009a)：健全な水循環の復活について http://www.city.nagoya.jp/shisei/category/ 53-5-22-6-0-0-0-0-0-0.html (2018年 3 月 7 日閲覧)
名古屋市 (2009b)：低炭素都市2050なごや戦略 http://www.city.nagoya.jp/shisei/category/ 53-5-22-1-3-0-0-0-0-0.html (2018年 3 月 7 日閲覧) 名古屋市 (2010)：生物多様性2050なごや戦略 http://www.city.nagoya.jp/shisei/category/ 53-5-22-2-1-0-0-0-0-0.html (2018年 3 月 7 日閲覧) 名古屋市 (2011)：第3次名古屋市環境基本計画 http://www.city.nagoya.jp/shisei/category/ 53-5-23-2-0-0-0-0-0-0.html (2018年 3 月 7 日閲覧) (受付：2017年 4 月26日, 受理：2018年 3 月16日) 